\title{
Assessment of Borehole Water Quality for Domestic Use in Three Selected Wards in Wudil Local Government Area, Kano State
}

\author{
B. U. Getso ${ }^{1}$, A. Mustapha ${ }^{2}$, M. M. Abubakar ${ }^{3} \&$ A. Tijjani ${ }^{1}$ \\ ${ }^{1}$ Department of Biology, Kano University of Science and Technology, Wudil, Nigeria \\ ${ }^{2}$ Department of Geography, Kano University of Science and Technology, Wudil, Nigeria \\ ${ }^{3}$ Department of Biological Sciences, Federal University Dutse, Nigeria \\ Correspondence: Adamu Mustapha, Department of Geography, Kano University of Science and Technology, \\ Wudil, Nigeria.
}

Received: May 12, 2018

Accepted: May 29, 2018

Online Published: June 6, 2018

doi:10.20849/jess.v1i1.394

URL: https://doi.org/10.20849/jess.v1i1.394

\begin{abstract}
The quality of water used for domestic purposes from three boreholes in Wudil Local Government (KUST Wudil, Unguwar Danya and Unguwar Fulani) was analyzed and assessed for a period of five weeks using standard methods of sampling and laboratory analysis. Parameters tested include $\mathrm{pH}$ dissolved oxygen (DO), five-day biochemical oxygen demand $\left(\mathrm{BOD}_{5}\right)$, nitrate ion $\left(\mathrm{NO}_{3}\right)$, conductivity, hardness, temperature total dissolved solids (TDS) and turbidity. Results showed that there are significant differences between the different wards. However, a one way ANOVA conducted reveals significant difference $(\mathrm{p}<0.05)$ between the different sites and physicochemical parameters. It is therefore recommended that government should be more effective in controlling the point source of pollution in the area.
\end{abstract}

Keywords: water quality, water pollution, one-way ANOVA, Wudil LGA

\section{Introduction}

Potable water is an essential ingredient for good health and the socio-economic development of man (Udom et al., 2002) but it's lacking in many societies. Clean water is priceless and a limited resource that man has begun to treasure only recently after decades of pollution and waste (Sinderberg, 2003). World population cannot be sustained without access to safe water (Brainstein, 2007). It is therefore important to conjunctly consider both water quality and quantity in water resources management (Xinghui et al., 2009). Borehole water become unsuitable for domestic use as a resource due to contamination that makes it unfit for many purposes (Agbaire \& Oyibi, 2009). The aim of water quality management is usually to minimize the health risks associated with either direct or indirect use of water (Udom et al., 2002). Standards and guidelines in water quality stem from the need to protect human health (Minh et al., 2011). Borehole water serves as the major source of drinking water in the local population of Nigeria. Since only few can afford and rely on purified and treated bottled water for consumption. Chapman (1996), stress the importance of groundwater as a source of potable water in Africa and constitutes about two thirds of the freshwater resources of the world. Ground water provides a reasonably constant supply for domestic use, livestock and irrigation. Carlow et al. (2011) stated this source can buffer the effects of rainfall variability across seasons. In many arid and semi-arid areas of Africa boreholes water is a mean of coping with water deficiencies in areas where rainfall is scarce or highly seasonal and surface water is extremely limited (Agbaire \& Oyibi, 2009).

Contamination of water bodies has increasingly become an issue of serious environmental concern. In the case of underground waters like bore holes, this may arise from construction process of a borehole, drilling fluids, chemical casings and other materials which may find their way into the well thereby polluting the water (Angulo et al., 1997). An open well during the construction stage can also be a direct route for contaminants from the surface to the aquifer thereby providing an ideal opportunity for chemical casing and bacteriological pollution to occur (Brainstein, 2007). Even if no source of anthropogenic contamination may exist, there is potential for natural levels of metals and other chemicals to be harmful to human health. The natural water analysis for physical and chemical properties including trace element content is very important for public health studies (Egwari \& Aboaba, 2002). These studies are also a main part of pollution studies in the environment. In this part 
of the globe, where access to potable water supply is low, given the fact that underground and surface waters are the commonest source of water to the poor. Paucity of data on the subject will only add to the need of more research on the subject. It is in view of this that different boreholes that supply water for domestic use in Wudil town were analyzed for quality parameters.

\section{Materials and Methods}

Wudil Local Government Area is situated in the southern part senatorial district of Kano State Nigeria, with an estimated land area of $458 \mathrm{~km}^{2}$. It is located between longitude $8^{\circ} 45^{\prime} \mathrm{E}$ and $8^{\circ} 57^{\prime} \mathrm{E}$ as well as between latitude $11^{\circ} 37^{\prime} \mathrm{N}-12^{\circ}$ and $11^{\circ} 56^{\prime} \mathrm{N}$. Samples were collected from three different locations in Wudil metropolis and the samples were labeled according to site. The first is located in Unguwar Fulani, the people living in this area use the water for domestic purpose such as washing, drinking, bathing, cooking and other purpose. The second site is located in Unguwar Danya, and people use the water wholly for domestic purpose such as washing, bathing, cooking, etc. the last is site C, located in Kano University of Science and Technology (KUST) Campus which is situated close to Faculty of Computing and Mathematical Sciences (FACMS). Staff and students use the water for daily domestic routines. Samples were collected once in a week for a period of five weeks between 9 a.m-12 p.m with standard sampling procedures observed.

Nine water quality parameters were selected for analysis, these being: dissolved oxygen (DO), five-day biochemical oxygen demand $\left(\mathrm{BOD}_{5}\right), \mathrm{pH}$, conductivity, temperature, nitrate $\left(\mathrm{NO}_{3}\right)$ and turbidity. Water temperature, DO, pH, conductivity, turbidity, Hardness and Total Dissolved Solids (TDS) of the borehole water samples were detected using multi-parameters monitoring instrument (YSI incorporated, yellow spring Ohio, and USA). $\mathrm{BOD}_{5}$ determination of the water samples was carried out using the standard method. The $\mathrm{DO}$ content was determined before and after the incubation. Sample incubation was for 5 days at $20^{\circ} \mathrm{C}$ in $\mathrm{BOD}_{5}$ bottle and $\mathrm{BOD}_{5}$ was calculated after the incubation period.

\section{Results and Analyses}

The results of this research are presented in Table 1 . Temperature ranges between $27^{\circ} \mathrm{C}-30.3^{\circ} \mathrm{C}, \mathrm{pH}(6.0-6.3)$, DO $(3.0-3.6 \mathrm{mg} / \mathrm{L})$ and $\mathrm{BOD}_{5}(1.1-1.9 \mathrm{mg} / \mathrm{L})$. Ranges for Electrical conductivity are $(1176-1178.3 \mu \mathrm{s} / \mathrm{cm})$ and TDS $(586.4-589 \mathrm{mg} / \mathrm{L})$. Nitrate records $(68.3-71.3 \mathrm{mg} / \mathrm{L})$, Turbidity $(9.6-11.4 \mathrm{NTU})$ and hardness $(601-601.5 \mathrm{mg} / \mathrm{L})$. There was no great variation in tested parameters by the weeks of sampling as the observed variations were little from the first to the fifth week.

Table 1. Mean variations in water quality parameters by the weeks of sampling

\begin{tabular}{lccccc}
\hline Parameters & Week 1 & Week 2 & Week 3 & Week 4 & Week 5 \\
\hline Temperature $\left({ }^{\circ} \mathrm{C}\right)$ & 30.3 & 29.3 & 27 & 28 & 27 \\
$\mathrm{pH}$ & 6.0 & 6.2 & 6.2 & 6.3 & 6.3 \\
$\mathrm{DO}(\mathrm{mg} / \mathrm{L})$ & 3.6 & 3.0 & 3.3 & 3.4 & 3.4 \\
$\mathrm{BOD}_{5}(\mathrm{mg} / \mathrm{L})$ & 1.9 & 1.7 & 1.3 & 1.5 & 1.1 \\
Conductivity $(\mu \mathrm{s} / \mathrm{cm})$ & 1177 & 1176 & 1178.3 & 1176.7 & 1177 \\
TDS $(\mathrm{mg} / \mathrm{L})$ & 587.5 & 586.4 & 589 & 587.1 & 587.5 \\
Nitrate $(\mathrm{mg} / \mathrm{L})$ & 70 & 68.3 & 71 & 69.3 & 71.3 \\
Turbidity $(\mathrm{NTU})$ & 10.7 & 9.6 & 11.0 & 11.4 & 10.7 \\
Hardness $(\mathrm{mg} / \mathrm{L})$ & 601.5 & 601.1 & 601.2 & 602.1 & 601 \\
\hline
\end{tabular}

The water quality parameters according to the different sites of sampling are presented in Table 2. KUST borehole records the highest temperature readings of $29^{\circ} \mathrm{C}$. This is followed by the Unguwar Fulani $28.6^{\circ} \mathrm{C}$ and Unguwar Danya borehole $\left(28^{\circ} \mathrm{C}\right)$. DO concentration was highest at Unguwar Fulani and Unguwar Danya boreholes and least concentration of DO was found in the KUST borehole. Unguwar fulani records the least $\mathrm{BOD}_{5}(0.5 \mathrm{mg} / \mathrm{L})$. Electrical conductivity and TDS were recorded highest in site Unguwar Danya followed Unguwar Fulani and lastly KUST water samples while Nitrate ion concentrations followed the order B $>$ A $>$ C. Turbidity was highest at site C (18NTU), followed by B (12NTU) and lastly A (2.0) NTU. Water Hardness was highest at site $B(1481.4 \mathrm{mg} / \mathrm{L})$ and least in site C $(121 \mathrm{mg} / \mathrm{L})$. 
Table 2. Mean variations in water quality parameters by the sites of sampling

\begin{tabular}{lccc}
\hline Parameters & Site A & Site B & Site C \\
\hline Temperature $\left({ }^{\circ} \mathrm{C}\right)$ & $\mathbf{2 8 . 6}$ & 28 & 29 \\
pH & $\mathbf{6 . 1}$ & 6.3 & 6.2 \\
DO $(\mathrm{mg} / \mathrm{L})$ & $\mathbf{3 . 6}$ & 2.9 & 3.5 \\
BOD $_{5}(\mathrm{mg} / \mathrm{L})$ & $\mathbf{2 . 2}$ & 0.5 & 1.8 \\
Conductivity $(\mu \mathrm{s} / \mathrm{cm})$ & $\mathbf{5 5 1}$ & 2640 & 340.0 \\
TDS $(\mathrm{mg} / \mathrm{L})$ & $\mathbf{2 7 5}$ & 1317 & 170.4 \\
Nitrate $(\mathrm{mg} / \mathrm{L})$ & $\mathbf{5 4 . 0}$ & 133.0 & 23.0 \\
Turbidity $(\mathrm{NTU})$ & $\mathbf{2 . 0}$ & 12.0 & 18.0 \\
Hardness $(\mathrm{mg} / \mathrm{L})$ & $\mathbf{2 0 2 . 2}$ & 1481.4 & 121.0 \\
\hline
\end{tabular}

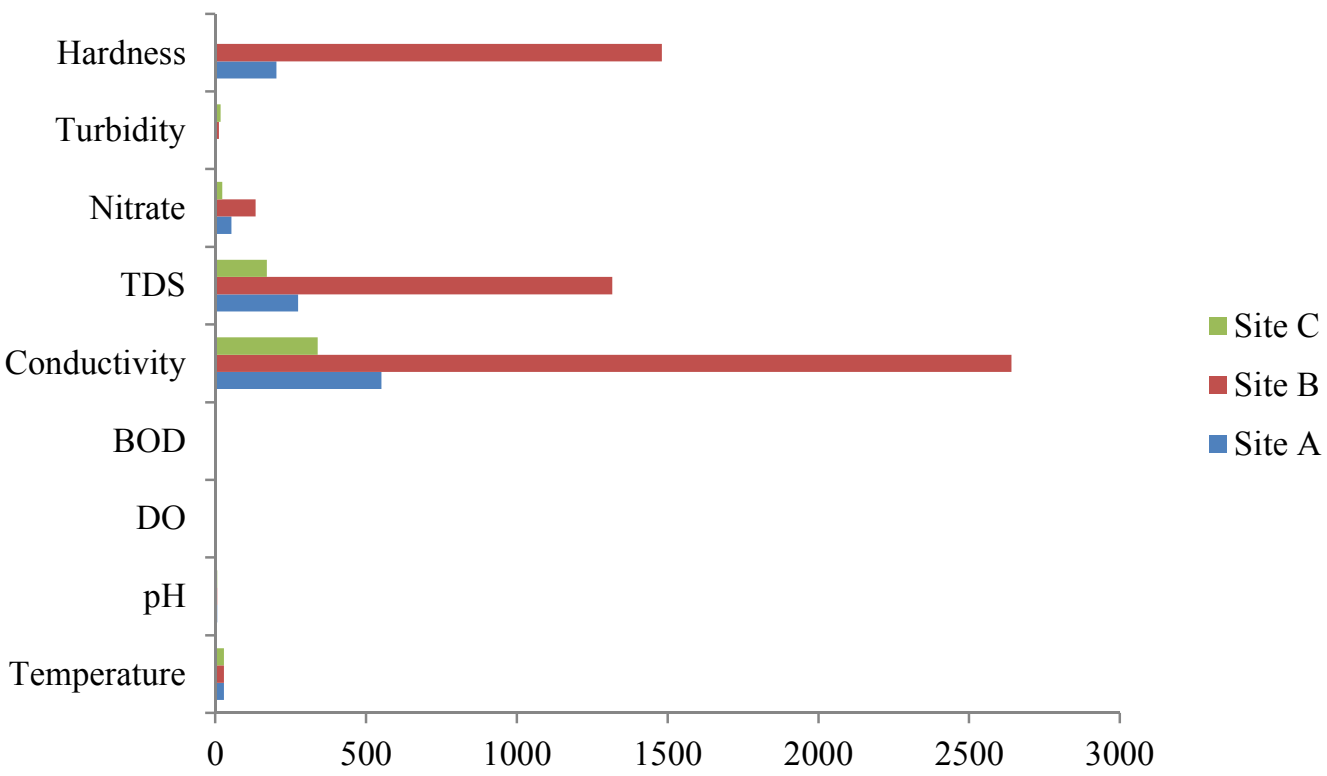

Figure 1 . Mean variations in water quality parameters by the sites of sampling

\section{Discussions}

It has already been established that temporal variations are negligible in this survey but the different sites of sampling shows considerable extremes. Observations on temperature recordings though slight may be due to site $\mathrm{C}$ (KUST borehole) being the last sampled during the survey as temperature of the day increases with time. The Unguwar Danya (site B) recorded the highest $\mathrm{pH}$ which is in conformity with readings of total hardness there. This could be from the basement material that could have carbonate, bicarbonate or hydroxide origins. Water hardness is an important component of water because it has a bearing on the portability of water as can be classified as soft, moderately hard, hard and very hard (EPA, 1986).

In general, $\mathrm{pH}$ was mildly acidic and does not fall between the range of World Health Organization (6.5-8.5) but agrees with Agbaire and Oyibo (2009), that the $\mathrm{pH}$ of most natural water falls between 6.0-9.0 because of the bicarbonate buffering. The "Unguwar Fulani" (site A) records the highest DO concentration which agrees with the lower temperature measurements. Similar results were found on the Biochemical oxygen Demand (an indicator of organic contamination). Least $\mathrm{BOD}_{5}$ was recorded at site $\mathrm{B}$ indicating most cleanliness from organic matter. Electrical conductivity (an estimate of total dissolved solids), shows higher readings in "Unguwar danya" borehole which is above the limit (TDS $500 \mathrm{mg} / \mathrm{L}$ ) set for drinking water. This can affect the aesthetic quality for use. This observation is attributed to characteristic of the soil and rocks that are present there. The remaining sites were far below the WHO recommended limit and thus okay for drinking. Rajana (2010) stated that 
palatability of water with TDS level less than $600 \mathrm{mg} / \mathrm{L}$ is generally considered to be good whereas water with TDS greater than $1200 \mathrm{mg} / \mathrm{L}$ become increasingly unacceptable. Results from Kotputli town in India Ranjana (2010), hints higher TDS associated with dry and low concentrations with rainy seasons respectively arguably from the dilution effect. This survey was conducted during the dry season. It is hoped that recordings could be low had rainy season been taken into account. KUST borehole was most turbid and Unguwar fulani was least. This is the only borehole that conforms to the 5NTU limit recommended for drinking by WHO. Since high turbidity values may increase the possibility of microbial contamination Rajana (2010), the need to closely watch these water sources deems imperative. Highest Nitrate concentration coincides with least dissolved oxygen at Unguwar Danya borehole. There was no marked relationship between nitrate concentration and BOD. From this study, it shows only C having a nitrate content which falls within the WHO (2004) standard for drinking water of $50 \mathrm{mg} / \mathrm{L}$.

A one-way between groups analysis of variance was performed to investigate the variations in the water quality physicochemical parameters obtained from Unguwar Fulani, Unguwar Danya and KUST boreholes in five weeks. The null hypothesis states that, there are no differences in the mean samples of borehole water quality between the three wards in Wudil Local Government under study. Preliminary assumption testing was conducted to check for normality and homogeneity of variance with no violation noted.

The ANOVA test (Table 3) revealed that there is statistically significant differences in the mean of physicochemical parameters under study. These results reject the null hypothesis and revealed that, all the physicochemical parameters differ between the sampling weeks.

Table 3. ANOVA Table showing mean variation of physicochemical parameters between the sampling weeks

\begin{tabular}{lccccc}
\hline & Sum of Squares & $\mathrm{df}$ & Mean Square & $\mathrm{F}$ & Sig. \\
\hline Temperature & 49.54 & 4 & 12.385 & $1.17634 \mathrm{E}+32$ & 0.000 \\
$\mathrm{pH}$ & 0.24 & 4 & 0.06 & $4.55909 \mathrm{E}+30$ & 0.000 \\
$\mathrm{DO}$ & 0.94 & 4 & 0.235 & $2.86038 \mathrm{E}+31$ & 0.000 \\
$\mathrm{BOD}_{5}$ & 2.16 & 4 & 0.54 & $3.75462 \mathrm{E}+32$ & 0.000 \\
Conductivity & 19.34 & 4 & 4.835 & $1.12117 \mathrm{E}+28$ & 0.000 \\
$\mathrm{TDS}$ & 24.94 & 4 & 6.235 & $1.15665 \mathrm{E}+29$ & 0.000 \\
$\mathrm{NO}_{3}$ & 30.34 & 4 & 7.585 & $4.50269 \mathrm{E}+30$ & 0.000 \\
Turbidity & 6.7 & 4 & 1.675 & $1.416 \mathrm{E}+31$ & 0.000 \\
Hardness & 0.7 & 4 & 0.175 & $3.24642 \mathrm{E}+27$ & 0.000 \\
\hline
\end{tabular}

\section{Conclusion}

It can be concluded that among the three boreholes surveyed, sites A and C (Unguwar Fulani and KUST boreholes respectively), possess better conditions for use as site B (the Unguwar Danya borehole) recorded extremes in nitrates, conductivity, DO and hardness which are not in conformity to the recommended limits for safe drinking water. Other parameters were of little effect on the quality of water from the sites of sampling.

It is recommended that appropriate regulatory agencies should carryout quality assessment of existing boreholes to ascertain their quality level of the water before allowing for public utilization. This will ensure that that incidence on contamination is noticed earlier for remedial action to be taken. Furthermore, this research shall be consolidated with rainy season data to investigate the level of dilution. Finally, analytical procedures on the nature of soil as it affects water quality for drinking need to be adopted and not just on the availability or not of water in an area before construction.

\section{References}

Agbaire, P. O., \& Oyibo, P. I. (2009). Seasonal variation of some Physico-chemical properties of borehole water in Abraka, Nigeria. African Journal of Pure and Applied Chemistry, 3(6), 116-118.

Angulo, F. J., S. Tippen, D. J. Sharp, B. J. Payne, C. Collier, J. E. Hill, ... D. L. Swerdlow. (1997). A community waterborne outbreak of Salmonellosis and the effectiveness of a boil water order. Am. J. Public Health, 87(4), 580-584. https://doi.org/10.2105/AJPH.87.4.580 
Brainstein, J. (2007). Trading the Rain, Should the World's fresh water resources be an international traded commodity?

Carlow C. Roger, Alan M. McDonald, Alan L. Nicol, \& Nick S. Robins. (2011). Groundwater Security and Drought in Africa. Linking Availability, Access and Demand.

Chapman, D. (1996). Water Quality Assessments. A guide to use biota, sediments and water in environmental monitoring (2nd ed.). Cambridge: University Press. https://doi.org/10.4324/NOE0419216001

Egwari, L., \& Aboaba, O. O. (2002). Bacteriological quality of domestic waters. Rev. SaudePublica, 36(4), 513-520. https://doi.org/10.1590/S0034-89102002000400019

Minh Phung T. Pham, James W. Castle, \& John H. Rodgers Jr. (2011). Application of water quality guidelines and water quantity calculations to decisions for beneficial use of treated water.

Rajana, A. (2010). Physico-Chemical Analysis of some Groundwater Samples of Kotputli Town Jaipur, Rajasthan India. Chemical, Environmental and Pharmaceutical Research, 1(2), 111-113.

Sinderberg, M. S. (2003). Higher Education Chemistry. In The Molecular Nature of Matter and Change. McGraw Hill.

Udom, G. J. Ushie, F. A., \& Esu, E. O. (2002). A geochemical survey of groundwater in Khana and Gokana local government area of Rivers State, Nigeria. J. Applied Sci. Environ. Manage, 6, 53-59. https://doi.org/10.4314/jasem.v6i1.17196

United States Environmental Protection Agency (USEPA). (1986). Method: 130.2: Hardness, Total (mg/L as CaCO3) (Titrimetric, EDTA). Methods for the Chemical Analysis of Water and Wastes (MCAWW) (EPA/600/4-79/020).

World Health Organization (WHO). (2004). Water, sanitation and hygiene links to health. $\mathrm{http} / /$ :www.who.int/water_sanitation_health/publications/facts2004/en/print.html

Xinghui, X. Zhifeng Y., \& Yuxiang W. (2009). Incorporating Eco-environmental Water Requirements in Integrated Evaluation of Water Quality and Quantity- A case study for the Yellow River. Water Resour Manage, 23, 1067-1079. https://doi.org/10.1007/s11269-008-9315-z

\section{Copyrights}

Copyright for this article is retained by the author(s), with first publication rights granted to the journal.

This is an open-access article distributed under the terms and conditions of the Creative Commons Attribution license (http://creativecommons.org/licenses/by/4.0/). 